\title{
Implikasi Hukum Ketidakpatuhan Korea Utara terhadap Resolusi Dewan Keamanan PBB dalam Uji Coba Nuklir
}

\author{
Nuraisah; Rika Erawaty \\ Fakultas Hukum Universitas Mulawarman \\ *Coresponding author: nuurraisyah927@yahoo.com \\ Submission $\quad: 16$ Februari 2021 \\ Revision : 01 Maret 2021 \\ Publication : 18 Maret 2021
}

\begin{abstract}
Since 2006 to 2017 the Security Council has passed a resolution on North Korea's nuclear test act. Article 25 of the UN Charter states that Members of the United Nations agree to accept and implement the decisions of the Security Council in accordance with this Charter. North Korea as a UN member state that obtained the UN Security Council Resolution is obliged to implement the sanctions resolution. However, the sanctions contained in the resolution did not make North Korea stop its nuclear program and it shows North Korea's noncompliance with UN Security Council resolutions. Implications accompanying any denial by North Korea against the UN Security Council resolution which in general affects four fields, namely the fields of economy, politics, defense and international cooperation. In addition to non-military sanctions, the Security Council under chapter VII Article 42 of the UN Charter can impose military sanctions where possible, the Security Council can also impose sanctions through the UN General Assembly on its recommendation to suspend the rights of UN membership) and expulsion of a country from UN membership).
\end{abstract}

Keywords: Non-Compliance; Nuclear; Resolution.

\section{Abstrak}

Sejak tahun 2006 hingga tahun 2017 Dewan Keamanan telah mengeluarkan resolusi atas tindakan uji coba nuklir Korea Utara. Pasal 25 Piagam PBB menyatakan bahwa Anggota-anggota 
Perserikatan Bangsa-Bangsa menyetujui untuk menerima dan menjalankan keputusan-keputusan Dewan Keamanan sesuai dengan Piagam ini. Korea Utara sebagai negara anggota PBB yang memperoleh Resolusi Dewan Keamanan PBB wajib melaksanakan sanksi resolusi. Namun sanksi yang tertuang dalam resolusi tidak membuat Korea Utara menghentikan program nuklirnya dan hal ini menunjukkan sikap ketidakpatuhan Korea Utara terhadap resolusi Dewan Keamanan PBB. Implikasi hukum menyertai setiap pengingkaran yang dilakukan Korea Utara terhadap resolusi Dewan Keamanan PBB yang secara garis besar berpengaruh pada empat bidang yakni bidang ekonomi, politik, pertahanan dan kerjasama internasional. Selain sanksi non-militer, Dewan Keamanan berdasarkan BAB VII Pasal 42 Piagam PBB dapat memberikan sanksi militer jika memungkinkan untuk dilakukan, Dewan Keamanan juga dapat memberikan sanksi melalui Majelis Umum PBB atas rekomendasinya berupa penangguhan hak-hak keanggotaan PBB dan pengusiran suatu negara dari keanggotaan PBB.

Kata Kunci: Ketidakpatuhan; Nuklir: Resolusi.

\section{A. Pendahuluan}

Salah satu upaya yang dilakukan PBB dalam menghadapi tantangan yang beragam khususnya dalam mencegah tindakan yang dapat mengancam keamanan dunia yakni dengan menghentikan uji coba nuklir dan seluruh program pengembangan senjata nuklir yang ada. Pengembangan nuklir Korea Utara merupakan salah satu upaya yang ditujukan untuk keperluan militer. Hal ini dibuktikan dengan uji coba nuklir sebagai bukti adanya pengembangan terhadap nuklir Korea Utara. Uji coba nuklir pertama kali dilakukan oleh Korea Utara tepatnya pada tanggal 9 Oktober 2006 di sebuah terowongan gunung di pantai timur wilayahnya. Dewan Keamanan menjatuhkan sanksi kepada 
Korea Utara dengan mengeluarkan Resolusi Nomor 1718 pada 14 Oktober 2006.

Ketidakpatuhan Korea Utara terhadap resolusi Dewan Keamanan PBB telah melanggar ketentuan Pasal 25 Piagam PBB yang menyatakan bahwa Anggota-anggota Perserikatan Bangsa-Bangsa menyetujui untuk menerima dan menjalankan keputusan-keputusan Dewan Keamanan sesuai dengan Piagam ini. Korea Utara sebagai negara anggota PBB yang memperoleh Resolusi Dewan Keamanan PBB wajib melaksanakan sanksi resolusi, namun pada kenyataannya Korea Utara melakukan pengingkaran kewajiban dengan melakukan uji coba nuklir secara berkelanjutan.

\section{B. Pembahasan}

\section{Resolusi Dewan Keamanan PBB Terhadap Korea Utara}

Resolusi Dewan Keamanan PBB adalah resolusi PBB yang ditetapkan lewat pemungutan suara dari hasil sidang yang dilakukan oleh lima anggota tetap dan sepuluh anggota tidak tetap Dewan Keamanan PBB tanpa adanya veto dari lima anggota tetap Dewan Keamanan PBB untuk menyelesaikan suatu sengketa internasional sebagai tanggung jawab utamanya dalam pemeliharaan perdamaian dan keamanan internasional. ${ }^{1}$

\section{Tabel 2.1}

\section{Resolusi Dewan Keamanan PBB Terhadap Uji Coba} Nuklir Korea Utara

1 Sri Setianingsih Suwardi, 2004, Pengantar Hukum Organisasi Internasional, Jakarta: Universitas Indonesia Press, hlm. 165. 


\begin{tabular}{|c|c|}
\hline $\begin{array}{l}\text { Resolusi DK } \\
\text { PBB }\end{array}$ & Isi Resolusi \\
\hline $\begin{array}{l}\text { Resolusi } \\
1718 \\
(14 \\
\text { Oktober } \\
2006)\end{array}$ & $\begin{array}{l}\text { 1. Mengecam uji coba nuklir pada } 9 \\
\text { Oktober } 2006 \text { serta larangan } \\
\text { melakukan uji coba nuklir lebih lanjut } \\
\text { atau peluncuran rudal balistik. } \\
\text { 2. Menarik pengumuman pengunduran } \\
\text { diri dari NPT. } \\
\text { 3. Menuntut kembali ke perjanjian IAEA } \\
\text { dan melanjutkan mematuhi kewajiban } \\
\text { yang tertuang dalam NPT. } \\
\text { 4. Menangguhkan semua kegiatan yang } \\
\text { berkaitan dengan program rudal } \\
\text { balistik. } \\
\text { 5. Semua Negara-negara Anggota PBB } \\
\text { harus mencegah penjualan atau } \\
\text { pemindahan bahan-bahan terkait } \\
\text { dengan program-program } \\
\text { pengembangan nuklir Pyongyang } \\
\text { seperti peralatan militer yakni tank } \\
\text { tempur, rudal, kendaraan tempur lapis } \\
\text { baja, sistem artileri kaliber besar, } \\
\text { pesawat tempur, helikopter dan kapal } \\
\text { perang. } \\
\text { Semua Negara Anggota membekukan } \\
\text { segera dana, aset keuangan lainnya dan } \\
\text { sumber daya ekonomi yang berada di } \\
\text { wilayah mereka yang berkaitan dengan } \\
\text { program pengembangan nuklir Korea } \\
\text { Utara. } \\
\text { Semua Negara Anggota melaporkan } \\
\text { kepada Dewan Keamanan terhadap } \\
\text { langkah-langkah yang telah diambil } \\
\text { sebagai bentuk implementasi dalam } \\
\text { waktu tiga puluh hari sejak adopsi } \\
\text { resolusi. }\end{array}$ \\
\hline $\begin{array}{lr}\text { Resolusi } & 1874 \\
(12 \quad \text { Juni } \\
2009)\end{array}$ & $\begin{array}{l}\text { 1. Mengecam uji coba nuklir yang } \\
\text { dilakukan pada } 25 \text { Mei } 2009 \text { yang } \\
\text { mengabaikan resolusi } 1718 \text { (2006) }\end{array}$ \\
\hline
\end{tabular}

Uti Possidetis: Journal of International Law, Vol. 2, No. 1 (2021) 
serta larangan untuk melakukan uji coba nuklir lebih lanjut atau peluncuran apapun menggunakan teknologi rudal balistik dan meninggalkan segala senjata nuklir yang ada.

2. Mempertajam larangan transaksi perdagangan termasuk transfer senjata serta larangan melakukan pelatihan teknis terkait dengan pembuatan, pemeliharaan atau penggunaan senjata.

3. Membatasi bantuan atau penyediaan layanan keuangan termasuk transfer keuangan dari setiap aset keuangan atau sumber daya lain yang dapat berkontribusi dalam pengembangan nuklir Korea Utara dan negara anggota juga tidak boleh memberikan pinjaman kepada Korea Utara kecuali untuk tujuan kemanusiaan.

4. Tidak memberikan dukungan keuangan publik untuk perdagangan terhadap Korea Utara termasuk pemberian kredit ekspor, jaminan atau asuransi kepada warga negara atau entitas yang terlibat dalam pengembangan nuklir.

5. Semua Negara Anggota melaporkan kepada Dewan Keamanan terhadap langkah-langkah yang telah diambil sebagai bentuk implementasi dalam waktu tiga puluh hari sejak adopsi resolusi.

6. Meminta Sekretaris Jenderal membentuk panel beranggotakan tujuh ahli untuk membantu komite 
sanksi dalam penegakan resolusi dan monitoring pelaksaanaan resolusi.

$\begin{array}{ll}\text { Resolusi } 2087 & \text { 1. Mengecam peluncuran rudal balistik } \\ (22 \text { Januari } & \text { pada 12 Desember 2012 yang } \\ \text { melanggar resolusi 1718 (2006) dan } \\ & \begin{array}{l}1874(2009) . \\ \end{array} \\ & 2 . \text { Menuntut Korea Utara segera } \\ & \text { memenuhi sepenuhnya kewajiban } \\ & \text { dalam resolusi 1718 (2006) dan 1874 } \\ & (2009)\end{array}$

3. Pembekuan aset terhadap 6 lembaga dan juga larangan perjalanan terhadap 4 individu Korea Utara yang memiliki peran utama dalam peluncuran nuklir Korea Utara.

4. Mendorong kesediaan badan-badan internasional dan keterlibatannya dengan komite untuk mengambil langkah-langkah dalam memastikan terlaksananya segala ketentuan resolusi.

Resolusi 2094

1. Mengecam uji coba nuklir pada 12

(7 Maret Februari 2013 yang melanggar resolusi 2013)

1718 (2006), 1874 (2009), dan 2087 (2013) serta larangan melakukan peluncuran nuklir lebih lanjut.

2. Pembekuan aset terhadap 2 lembaga dan juga larangan perjalanan terhadap 3 individu Korea Utara yang memiliki peran utama dalam peluncuran nuklir Korea Utara.

3. Larangan pembukaan cabang baru, anak perusahaan, atau kantor perwakilan dari bank Korea Utara di negara-negara anggota PBB serta melarang Bank Korea Utara untuk mendirikan usaha patungan baru dari kepemilikan saham. 


\begin{tabular}{ll}
\hline & 4. Melarang Negara Anggota PBB \\
& membuka lembaga keuangan di Korea \\
& Utara. \\
& 5. Tidak memberikan dukungan \\
& keuangan publik untuk perdagangan \\
& terhadap Korea Utara termasuk \\
& pemberian kredit ekspor, jaminan atau \\
& asuransi kepada warga negara atau \\
& entitas yang terlibat dalam \\
& pengembangan nuklir. \\
& 6. Memperkuat otoritas negara untuk \\
& memeriksa kargo yang dicurigai berisi \\
& barang-barang penjualan yang dilarang \\
& oleh resolusi 1718, 1874 dan 2087 \\
& serta menolak akses pelabuhan serta \\
& penerbangan terhadap pengiriman \\
& terkait Korea Utara. \\
& 7. Larangan transfer barang mewah ke \\
& Korea Utara yakni beberapa jenis \\
& perhiasan seperti perhiasan mutiara, \\
& batu mulia dan perhiasan logam mulia \\
& serta barang-barang transportasi \\
& seperti kapal pesiar, mobil mewah dan \\
& mobil balap. \\
\hline 1. Mengecam uji coba nuklir pada 6 \\
Januari 2016 yang melanggar resolusi \\
1718 (2006), 1874 (2009), 2087 dan \\
2094 (2013) serta larangan melakukan \\
peluncuran nuklir lebih lanjut. \\
2. Larangan semua Negara Anggota \\
mengadakan latihan khusus dan \\
melakukan pengajaran terhadap \\
disiplin ilmu fisika, ilmu komputer, \\
navigasi geospasial, teknik nuklir, \\
teknik luar angkasa, teknik \\
penerbangan yang mendukung \\
pengembangan nuklir Korea Utara. \\
3. Negara anggota PBB memperketat \\
pemeriksaan muatan kargo yang \\
\hline Maret
\end{tabular}

Uti Possidetis: Journal of International Law, Vol. 2, No. 1 (2021) 
masuk dan keluar dari Korea Utara dan melarang ekspor barang tambang Korea Utara.

4. Melarang pemasokan batu bara, besi dan bijih besi, emas, bijih titanium, bijih vanadium, dan logam tanah jarang oleh Korea Utara.

5. Melarang Negara Anggota untuk memasok bahan bakar pesawat terbang dan roket ke Korea Utara.

6. Pembekuan aset terhadap 12 lembaga dan 16 individu dimasukkan kedalam daftar hitam, termasuk 39 Partai berkuasa, Partai Buruh Korut.

Resolusi 2321 1. Mengecam uji coba nuklir pada 9 (30

November 2016) September 2016 yang melanggar resolusi 1718 (2006), 1874 (2009), 2087 dan 2094 (2013) serta 2270 (2016) serta larangan melakukan peluncuran nuklir lebih lanjut.

2. Negara Anggota PBB membatasi jumlah Bank yang berkontribusi pada misi diplomatik dan konsuler Korea Utara.

3. Larangan terhadap Diplomat untuk menggunakan atau menyewakan bangunan di wilayah negara penerima diluar kegiatan diplomatik atau konsuler.

4. Membatasi ekspor batu bara ke Korea Utara.

5. Melarang Korea Utara untuk ekspor tembaga, nikel, perak dan seng.

6. Pembekuan aset terhadap 10 lembaga dan juga larangan perjalanan terhadap 11 individu Korea Utara yang miliki peran utama dalam peluncuran nuklir Korea Utara. 
Resolusi 2371 (5 Agustus 2017)
1. Mengecam uji coba nuklir pada 3 Juli dan 28 Juli 2017 yang melanggar resolusi 1718 (2006), 1874 (2009), 2087 dan 2094 (2013) serta 2270 dan 2321 (2016) serta larangan melakukan peluncuran nuklir lebih lanjut.

2. Larangan untuk memasok atau menjual batu bara, besi, bijih besi dan boga laut termasuk ikan, krustasea, moluska, dan invertebrata air lainnya serta timah dan biji timah ke negara lain.

3. Membatasi jumlah otorisasi tenaga kerja untuk Korea Utara yang diberikan dalam yuridiksi Negara Anggota.

4. Larangan membuat perjanjian investasi apapun sebagai perluasan usaha patungan oleh Negara Anggota dalam bentuk perusahaan maupun pribadi dengan Korea utara.

5. Pembekuan aset terhadap 4 perusahaan dan juga larangan perjalanan terhadap 9 individu Korea Utara yang memiliki peran utama dalam peluncuran nuklir Korea Utara.

6. Semua Negara Anggota melaporkan kepada Dewan Keamanan terhadap langkah-langkah yang telah diambil sebagai bentuk implementasi dalam waktu sembilan puluh hari sejak adopsi resolusi.

Resolusi 2375 (11Septembe r 2017)
1. Mengecam uji coba nuklir pada 2 September 2017 yang melanggar resolusi 1718 (2006), 1874 (2009), 2087 dan 2094 (2013), 2270 dan 2321 (2016), 2371 (2017) serta larangan melakukan peluncuran nuklir lebih lanjut. 
2. Negara Anggota dilarang untuk memasok, menjual, atau mengalihkan cairan kondesat dan gas alam ke Korea Utara.

3. Larangan pengiriman, penjualan atau pengalihan semua produk minyak sulingan di luar 500.000 barel ke Korea Utara selama periode awal tiga bulan dimulai pada tanggal 1 Oktober 2017 dan berakhir pada 31 Desember 2017, dan melebihi 2 juta barel per tahun selama periode 12 bulan mulai tanggal 1 Januari 2018 dan setiap tahun setelahnya.

4. Negara Anggota dilarang memasok, menjual atau mentransfer minyak mentah ke Korea Utara dalam periode 12 Bulan setelah adopsi resolusi ini.

5. Larangan terhadap Korea Utara untuk memasok atau menjual produk tekstilnya seperti kain dan pakaian jadi. 6. Negara Anggota dilarang memberikan izin kerja untuk warga negara Korea Utara di yurisdiksi mereka.

7. Negara anggota harus melarang pembukaan, pemeliharaan, dan operasi semua usaha patungan atau entitas koperasi baik yang baru maupun yang sudah ada dengan entitas atau individu Korea Utara yang bertindak atas nama pemerintah Korea Utara oleh warga negaranya maupun di wilayah negaranya.

8. Menekankan penghormatan terhadap Hak Asasi Manusia yang mengabaikan kesejahteraan warga negaranya demi kesuksesan pengembangan nuklirnya. 


\begin{tabular}{|c|c|}
\hline & $\begin{array}{l}\text { 9. Pembekuan aset terhadap } 3 \\
\text { perusahaan dan juga larangan } \\
\text { perjalanan terhadap } 1 \text { individu Korea } \\
\text { Utara yang memiliki peran utama } \\
\text { dalam peluncuran nuklir Korea Utara. }\end{array}$ \\
\hline $\begin{array}{l}\text { Resolusi } 2397 \\
\text { (22 Desember } \\
\text { 2017) }\end{array}$ & $\begin{array}{l}\text { 1. Mengecam uji coba nuklir melalui } \\
\text { peluncuran rudal balistik pada } 28 \\
\text { November } 2017 \text { yang melanggar } \\
\text { resolusi } 1718 \text { (2006), } 1874 \text { (2009), } \\
2087 \text { dan } 2094(2013), 2270 \text { dan } 2321 \\
\text { (2016), } 2371 \text { dan } 2375 \text { (2017) serta } \\
\text { larangan melakukan peluncuran nuklir } \\
\text { lebih lanjut. } \\
\text { 2. Negara Anggota harus melarang } \\
\text { pasokan, penjualan ke Korea Utara dari } \\
\text { semua minyak mentah dan larangan } \\
\text { ini tidak berlaku berkenaan dengan } \\
\text { minyak mentah untuk jangka waktu } \\
\text { dua belas bulan setelah tanggal adopsi } \\
\text { resolusi ini dan untuk periode dua } \\
\text { belas bulan sesudahnya tidak melebihi } \\
4 \text { juta barel atau } 525.000 \text { ton. } \\
\text { 3. Negara anggota dilarang memasok, } \\
\text { menjual, atau mengalihkan semua } \\
\text { produk minyak bumi dan ketentuan ini } \\
\text { tidak berlaku sehubungan dengan } \\
\text { pengadaan, penjualan atau pasokan } \\
\text { oleh Korea Utara terhadap produk } \\
\text { minyak sulingan, termasuk solar dan } \\
\text { minyak tanah dengan jumlah } \\
\text { keseluruhan sampai } 500.000 \text { barel } \\
\text { selama periode dua belas bulan yang } \\
\text { dimulai pada tanggal } 1 \text { Januari } 2018 \text {, } \\
\text { dan untuk periode dua belas bulan } \\
\text { sesudahnya. } \\
4 \text { Korea Utara dilarang untuk } \\
\text { menyediakan atau menjual produk } \\
\text { makanan dan pertanian, mesin, } \\
\text { peralatan listrik, tanah dan batu }\end{array}$ \\
\hline
\end{tabular}


termasuk magnesit dan magnesia, kayu, dan kapal.

5. Negara Anggota dilarang memasok atau menjual semua mesin industri, kendaraan pengangkutan dan besi, baja dan logam ke Korea Utara.

6. Negara Anggota harus memulangkan warga negara Korea Utara yang memperoleh penghasilan di wilayah negaranya.

7. Pembekuan aset terhadap 1 perusahaan dan juga larangan perjalanan terhadap 16 individu Korea Utara yang memiliki peran utama dalam peluncuran nuklir Korea Utara.

\section{Sikap Korea Utara terhadap Resolusi Dewan keamanan PBB}

Terdapat beberapa sikap yang ditunjukkan oleh Korea Utara sebagai bentuk reaksi Korea Utara terhadap resolusi yang diberikan oleh Dewan Keamanan.

Tabel 2.2

Sikap Korea Utara Terhadap Resolusi Dewan Keamanan PBB

\begin{tabular}{lll}
\hline $\begin{array}{l}\text { Resolusi } \\
\text { PBB }\end{array}$ & \multicolumn{2}{l}{ Sikap Korea Utara } \\
\hline Resolusi 1718 & 1. & Korea Utara melalui utusannya \\
(2006) & & pak Gil Yon menyatakan menolak \\
& segala ketentuan yang ada di \\
& & dalam resolusi tersebut dan \\
& melakukan aksi walk out dari \\
& ruang persidangan PBB.
\end{tabular}

2 BBC News, 2006, UN slaps sanctions on North Korea, http://news.bbc.co.uk/2/hi/asia-pacific/6051704.stm, diakses pada 1 April 2020, Pukul 10.00 WITA.

Uti Possidetis: Journal of International Law, Vol. 2, No. 1 (2021) 
2. Berdasarkan laporan dari badan nuklir PBB pada Februari 2007 Korea Utara bersepakat dengan IAEA (International Atomic Energy Agency) mengenai berbagai langkah yang perlu ditempuh untuk menutup reaktor nuklir utama mereka dengan tujuan untuk mendapatkan bantuan internasional yakni bantuan bahan bakar sebanyak 50 ribu ton setelah penutupan reaktor nuklir tahap pertama pada 9 Juli 2007 kemudian bahan bakar sebanyak 950 ribu ton setelah terjadinya denuklirisasi di Korea utara serta menghapuskan citra Korea utara sebagai negara teroris. ${ }^{3}$

3. Korea Utara membangun kembali program pengembangan senjata nuklir Korea Utara pada tahun 2009 yang dibuktikan dengan uji coba nuklir pada 25 Mei 2009 akibat melemahnya aspek perekonomian dan kondisi pertahanan Korea Utara atas penghentian bahan bakar oleh Amerika Serikat yang telah melanggar perjanjian yang telah disepakati sebelumnya. ${ }^{4}$

3 BBC News, 2007, Perlucutan nuklir Korut rumit, http://www.bbc.co.uk/indonesian/news/sto ry/2007/03/070312 northkorea.shtml, diakses pada 1 April 2020, Pukul 13.00 WITA.

4 Tan Er-Win, North Korea's Rocket and Nuclear Tests, 2009: A Threatening Pyongyang or an Afraid Pyongyang?, JA Vol. XL, No. 3, September 2009, hlm. 552.

Uti Possidetis: Journal of International Law, Vol. 2, No. 1 (2021) 


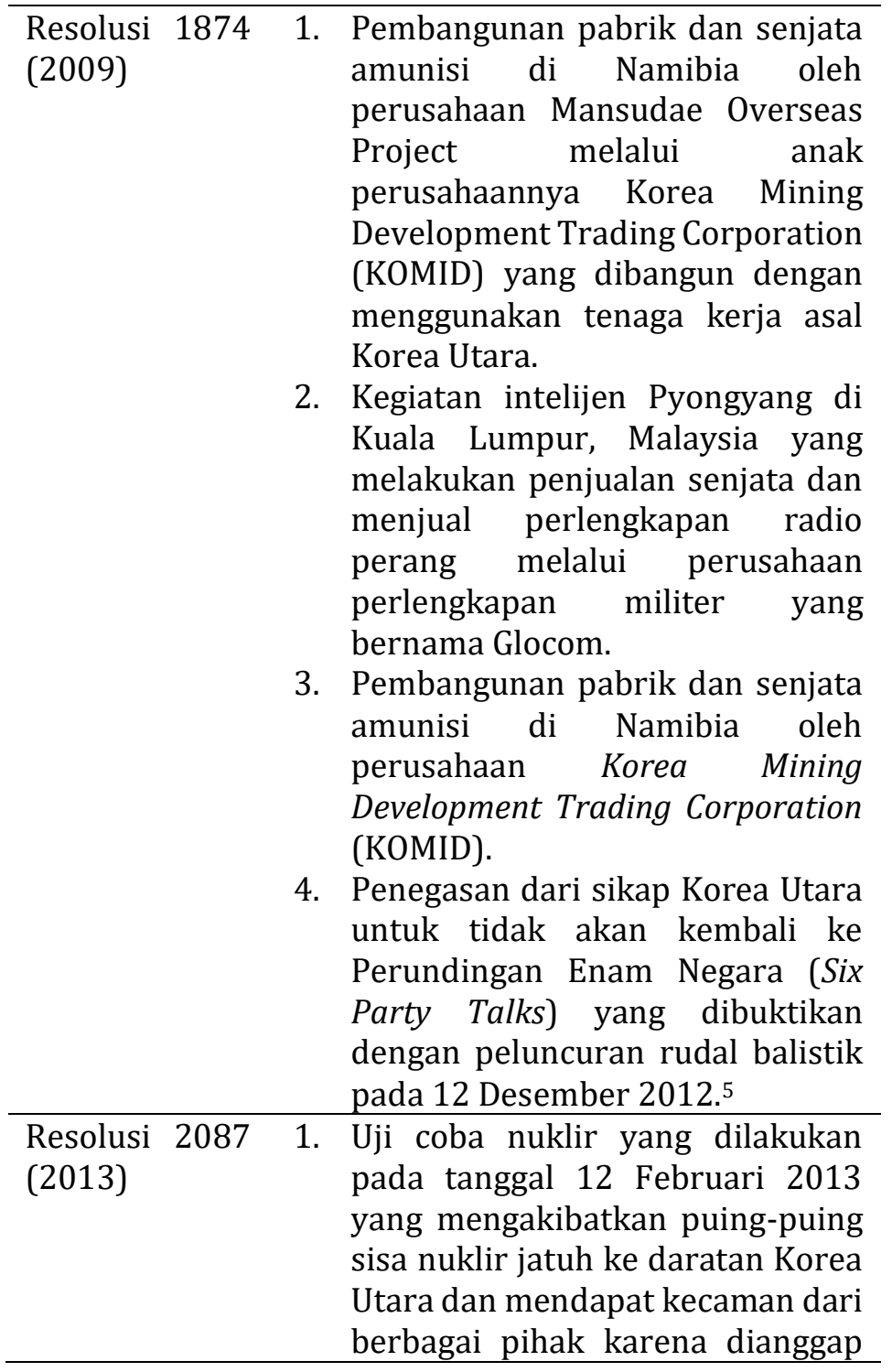

5 The National Committee on North Korea, 2009, DPRK's foreign ministry vehemently refutes UNSC's 'Presidential Statement, http://www.ncnk.org/resources/publications/KCNA DPRK Respons e UNSC April 1309 Statement.doc, diakses pada 19 April 2020, Pukul 20.00 WITA.

Uti Possidetis: Journal of International Law, Vol. 2, No. 1 (2021) 
Implikasi Hukum Ketidakpatuhan Korea Utara...

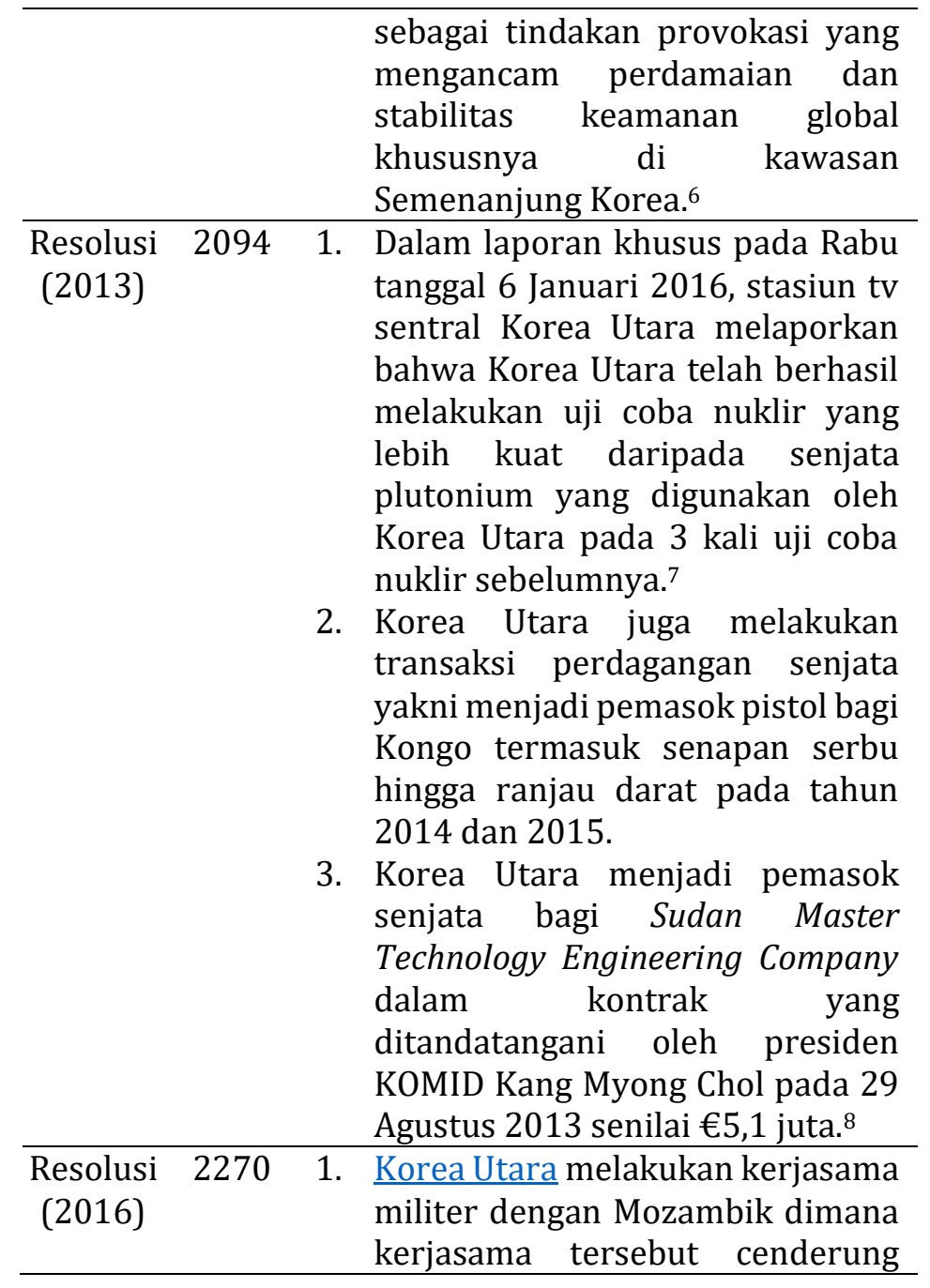

${ }^{6}$ Chrisyela Sinaga, Tinjauan Hukum Internasional Terhadap Ujicoba Nuklir Korea Utara Dan Kaitannya Dengan Perdamaian Dan Stabilitas Keamanan Global, JUIL Vol. I, No. 3, 2013, hlm. 4.

${ }^{7}$ Euan McKirdy, North Korea announces it conducted nuclear test, http://edition.cnn.com/2016/01/05/asia/north-korea-seismicevent/, diakses pada 4 April 2020, Pukul 08.00 WITA.

${ }^{8}$ Yantina Debora, 2017, Cara Korea Utara Mengakali Embargo PBB, https://tirto.id/cara-korea-utara-mengakali-embargo-pbbckQh, diakses pada 1 April 2020. Pukul 15.00 WITA.

Uti Possidetis: Journal of International Law, Vol. 2, No. 1 (2021) 
berfokus pada penjualan berbagai jenis rudal, radar militer, sistem pertahanan udara, dan senjata perang dengan keuntungan senilai US\$ 6 juta, atau sekitar Rp 80,5 miliar. ${ }^{9}$

2. Korea Utara telah menginspeksi sejumlah hulu ledak nuklir yang dirancang untuk reaksi thermonuklir yakni jenis yang digunakan pada bom hidrogen serta mampu mengecilkan hulu ledak nuklir. ${ }^{10}$

3. Korea Utara kembali meluncurkan nuklirnya pada 9 September 2016 yang mengancam wilayah Jepang dan Korea Selatan sebagai tanggapan atas kegiatan latihan militer gabungan antara Amerika Serikat dengan Korea Selatan yang menganggap latihan tersebut sebagai kekuatan musuh yang sedang melakukan persiapan untuk mengadakan invasi ke Korea Utara. ${ }^{11}$

9 Happy Ferdian Syah Utomo, 2018, Terungkap, Manisnya Bisnis Gelap Korea Utara di Mozambik,https://www.liputan6.com/global/read/3256360/terung kap-manisnya-bisnis-gelap-korea-ut ra-di-mozambik, diakses pada 1 April 2020, Pukul 19.00 WITA.

10 BBC News, 2016, Kim Jong-un klaim Korut punya hulu ledak nuklir mini, https://www.bbc.co m/indonesia/dunia/2016/03/160308_dunia_korut_hulu_ledak_nukl ir, diakses pada 7 April 2020, Pukul 08.00 WITA.

11 United States Forces Korea, 2016, CFC begins Ulchi Freedom Guardian 2016 ROK-US Combi ned Forces Command, 2016 Eulji Freedom Guardian Practice, https://www.usfk.mil/Media/Press-Rel eases/Article/920965/cfc-begins-ulchi-freedom-guardian-20162016/, diakses pada 6 April 2020, Pukul 21.00 WITA. 


\begin{tabular}{|c|c|}
\hline $\begin{array}{l}\text { Resolusi } 2321 \\
(2016)\end{array}$ & $\begin{array}{l}\text { Menyewakan sebagian } \\
\text { properti yang tidak terpakai di } \\
\text { kompleks diplomatik yang } \\
\text { terletak di pusat Berlin, kepada } \\
\text { City Hostel sebesar } 17 \text { euro } \$ \\
\text { 18)/malam dan bangunan lain } \\
\text { di properti disewakan sebagai } \\
\text { ruang acara berlangsung } \\
\text { selama hampir } 1 \text { dekade } \\
\text { dengan keuntungan puluhan } \\
\text { ribu euro per bulannya yang } \\
\text { digunakan untuk membeli } \\
\text { teknologi, barang mewah serta } \\
\text { hal-hal lain yang tidak ada } \\
\text { keterkaitan dengan misi } \\
\text { diplomatik Korea Utara. }{ }^{12} \\
\text { Korea Utara juga kembali } \\
\text { melakukan peluncuran rudal } \\
\text { balistik antar benua pada } \\
\text { tanggal } 3 \text { Juli dan } 28 \text { Juli } 2017 \\
\text { yang jatuh di wilayah Zona } \\
\text { Ekonomi Ekslusif Jepang dan } \\
\text { Tokyo menyebutnya sebagai } \\
\text { tindakan provokasi } \\
\text { Pyongyang. }\end{array}$ \\
\hline $\begin{array}{l}\text { Resolusi } 2371 \\
(2017)\end{array}$ & $\begin{array}{l}\text { 1. Korea Utara melakukan uji } \\
\text { coba rudal balistik antar benua } \\
\text { (ICBM) yang dilakukan oleh } \\
\text { Korea Utara pada tanggal } 3 \\
\text { September } 2017 \text {. }\end{array}$ \\
\hline $\begin{array}{l}\text { Resolusi } 2375 \\
(2017)\end{array}$ & $\begin{array}{l}\text { 1. Korea Utara melakukan uji } \\
\text { coba rudal ICBM yakni jenis } \\
\text { Hwasong-15 } \quad \text { pada }\end{array}$ \\
\hline
\end{tabular}

12 Chase Winter, 2017, DW Made For Minds, Germany To Strengthen Sanctions Against North Korea, https://www.dw.com/en/germany-to-strengthen-sanctions-againstnorth-korea/a-38777704, dia kses pada 1 Juni 2020, Pukul 03.00 WITA.

Uti Possidetis: Journal of International Law, Vol. 2, No. 1 (2021) 


\begin{tabular}{ll}
\hline & \multicolumn{2}{l}{$\begin{array}{l}\text { November 2017 yang diklaim } \\
\text { mampu membawa hulu ledak } \\
\text { nuklir dan jangkauannya } \\
\end{array}$} & $\begin{array}{l}\text { mencapai seluruh wilayah } \\
\end{array}$ & Amerika Serikat. \\
\hline Resolusi 2397 & Korea Utara melakukan \\
(2017) & peluncuran rudal nuklir di \\
& lokasi peluncuran satelit Sohae \\
& pada 13 Desember 2019 yang \\
& merupakan percobaan kedua \\
& yang dilakukan di Sohae. \\
\hline
\end{tabular}

Uji coba nuklir yang dilakukan Korea Utara merupakan suatu tindakan nyata bahwa Korea Utara secara terbuka menunjukkan reaksi penolakan terhadap larangan untuk tidak melakukan uji coba nuklir dan segera meninggalkan program nuklir yang ada serta pengingkaran terhadap sanksi yang dijatuhkan dalam resolusi Dewan Keamanan. Sikap Korea Utara dalam menanggapi resolusi Dewan Keamanan membuktikan bahwa implementasi terhadap Resolusi Dewan Keamanan PBB mengalami hambatan. ${ }^{13}$

Lebih dalam lagi, ketidakpatuhan Korea Utara terhadap resolusi Dewan Keamaman PBB dan tetap mengembangkan program nuklirnya adalah untuk mempertahankan atau memperkuat rezim pemerintahan yang saat ini berkuasa. Sebagai negara yang "tertutup", pengembangan nuklir juga

${ }^{13}$ I Wayan Nugraha Adi Sanjaya, Implementasi Resolusi Dewan Keamanan Perserikatan Bangsa-Bangsa Nomor 2270 Tahun 2016 Tentang Uji Coba Senjata Nuklir Oleh Korea Utara, JIH Vol. VI, No. 1, Januari 2018, hlm. 9.

Uti Possidetis: Journal of International Law, Vol. 2, No. 1 (2021) 
menjadi senjata negosisasi untuk mendapatkan bantuan ekonomi dan juag sebagai "alat" negosiasi dengan Amerika Serikat.

\section{Implikasi Hukum Ketidakpatuhan Korea Utara terhadap Resolusi Dewan Keamanan PBB}

Implikasi hukum menyertai setiap pengingkaran yang dilakukan terhadap resolusi Dewan Keamanan PBB pada empat bidang. Pertama, bidang ekonomi melalui sanksi ekonomi yang tertuang dalam kesembilan resolusi yakni resolusi 1718 (2006) hingga resolusi 2397 (2017) berupa larangan ekspor dan impor peralatan militer, larangan penjualan batu bara, besi dan bijih besi, emas, bijih titanium, bijih vanadium, dan logam tanah jarang oleh Korea Utara serta mengimpor bahan bakar pesawat terbang dan roket ke Korea Utara yang mengakibatkan pertumbuhan ekonomi Korea Utara turun sebesar 3,5 persen pada tahun $2016 .{ }^{14}$

Resolusi Dewan Keamanan juga berdampak pada hubungan ekonomi antara Korea Utara dan Cina, Ekspor dan Impor antara Korea Utara dan Cina mengalami penurunan pada bulan september 2017, ekspor ke Korea Utara merosot dari US\$315,97 juta menjadi US\$266,35 juta, sedangkan impor dari Korea Utara turun menjadi US $\$ 145,82$ juta dari US $\$ 288,29$ juta.

14 Gina Heeb, 2018, Sanctions are crippling North Korea's economy, https://markets.businessin sider.com/news/stocks/northkorea-economy-hit-by-sanctions-2018-7-1027386898, diakses pada 28 April 2020, Pukul 23.00 WITA.

Uti Possidetis: Journal of International Law, Vol. 2, No. 1 (2021) 
Kedua, bidang politik dimana terdapat sanksi politik berupa pemutusan diplomatik dan pengusiran Duta Besar Korea Utara di negara penerima yang tertuang dalam resolusi nomor 2270 dan 2321 (2016) serta 2371 (2017). Pemutusan hubungan diplomatik antara Korea Utara dengan Korea selatan bermula dengan adanya kerjasama internasional antara angkatan bersenjata Amerika Serikat dan Korea Selatan yang memulai latihan perang bersama. ${ }^{15}$ Pemutusan diplomatik juga dilakukan oleh Portugis secara resmi pada Juli 2017 setelah 42 tahun kedua negara menjalin hubungan diplomatik. ${ }^{16}$

Pengusiran Duta Besar Korea Utara juga dilakukan oleh beberapa negara seperti Meksiko yang mengusir Duta Besar Korea Utara dari Negeri Aztec pada 7 September sebagai bentuk protes atas uji coba nuklir keenam Korea Utara, Kementerian Luar Negeri Peru yang memberikan persona non-grata kepada Duta Besar Korea Utara Kim Hak-chol. ${ }^{17}$ Kuwait pun mengumumkan langkah serupa pada 18 September dan memutuskan untuk berhenti mengeluarkan visa ke Korut serta

15 Muhammad Farid Arpan, Motivasi Korea Utara Memutuskan Hubungan Kerjasama Dengan Korea Selatan Di Kawasan Industri Kaesong, JOM FISIP Vol. V, No. 1, April 2018, hlm. 6.

16 KBS WORLD RADIO, 2017, VOA: Portugis Memutus Hubungan Diplomatik dengan Korut, http://world.kbs.co.kr/service/news view.htm?lang=i\&Seq Code=4 7565, diakses pada 28 April 2020, Pukul 19.00 WITA.

17 Khairisa Ferida, 2017, Dubes Korea Utara Diminta Angkat Kaki dari Italia, https://www.liputa n6.com/global/read/3114082/dubes-korea-utara-diminta-angkatkaki-dari-italia, diakses pada 29 April 2020, Pukul 20.15 WITA. 
menangguhkan seluruh hubungan dagang dan penerbangan dengan Pyongyang18 dan pada 18 September 2017 Duta Besar Korea Utara di Spanyol juga telah dinyatakan persona non grata. ${ }^{19}$

Menteri Luar Negeri Italia, Angelino Alfano melakukan pengusiran terhadap Duta Besar Korea Utara, Mun Jong-nam di Italia dan memerintahkan untuk menanggalkan jabatannya pada awal Oktober 2017. Mun Jong-nam diprotes atas uji coba nuklir oleh Korea Utara pada September 2017. ${ }^{20}$ Pada 20 Oktober 2017, Pemerintah Myanmar telah melakukan pengusiran terhadap diplomat asal Korea Utara, Kim Chol Nam yang bekerja sebagai Sekretaris Kedua kedutaan Korea Utara di Myanmar. ${ }^{21}$

Ketiga, bidang pertahanan di dalam suatu Resolusi Dewan Keamanan PBB berupa sanksi impor terhadap material pembuat senjata nuklir dan peralatan-peralatan militer seperti tank tempur, kendaraan tempur lapis baja, sistem artileri

18 Khairisa Ferida, 2017, Kuwait Usir Dubes Korea Utara, https://www.liputan6.com/global/rea d/3099122/kuwait-usirdubes-korea-utara, diakses pada 29 April 2020, Pukul 21.00 WITA.

19 Teguh Firmansyah, 2017, Pemerintah Spanyol Usir Dubes Korut, https://www.republika.co. id/berita/internasional/global/17/09/19/owigqn377-pemerintahspanyol-usir-dubes-korut, diakses pada 29 April 2020, Pukul 21.45 WITA.

${ }^{20}$ KBS WORLD RADIO, Loc.cit.

21 Choirul Aminuddin, 2017, Myanmar Usir Diplomat Korea Utara Terkait Sanksi PBB, https://duni a.tempo.co/read/1026554/myanmar-usir-diplomat-korea-utaraterkait-sanksi-pbb/full\&view=ok, diakses pada 29 April 2020, Pukul 19.50 WITA.

Uti Possidetis: Journal of International Law, Vol. 2, No. 1 (2021) 
kaliber besar, pesawat tempur, helikopter serang, dan kapal perang sebagai akibat atas pelaksanaan resolusi 1718 tahun 2006.

Terdapat juga larangan impor bahan bakar penerbangan dan roket bagi Korea Utara yang mendukung perlengkapan milliter Korea Utara sebagai akibat atas pelaksanaan resolusi 2270 dan 2321 tahun 2016. Kemudian Negara Anggota dilarang mengimpor suku cadang pesawat terbang sebagai akibat atas pelaksanaan resolusi nomor 2397 tahun 2017, namun beberapa suku cadang pesawat terbang untuk kepentingan sipil tetap diperbolehkan sesuai dengan resolusi yang berlaku.

Keempat, bidang kerjasama internasional seperti Mesir yang mengakhiri semua ikatan militer dengan Korea Utara yang berfokus pada jual beli senjata, khususnya rudal jarak menengah. ${ }^{22}$ Filipina dan Singapura juga turut menghentikan seluruh kerjasama yang meliputi hubungan dagang dengan Korea Utara. Menteri Luar Negeri Jerman, Martin Schäfer menyatakan bahwa segala bentuk kegiatan yang berhubungan dengan Kedutaan Besar Korea Utara di Jerman dilarang dan pemerintah harus mematikan sumber pendapatan Korea Utara. $^{23}$

22 Emirald Julio, 2017, Oke News, https://news.okezone.com/read/2017/09/13/18/1774655/ tegasmesir-hentikan-kerjasama-militer-dengan-korea-utara, diakses pada 08 Juni 2020, Pukul 14.00 WITA.

23 BBC News, 2017, North Korea's Berlin hostel targeted by German sanctions, https://www.bb c.com/news/world-europe39882199, diakses pada 8 Juni 2020, Pukul 15.00 WITA. 
Uganda juga menjadi negara yang turut memutus hubungan militer dengan Korea Utara dimana sebelumnya antara Uganda dan Korea Utara memiliki hubungan diplomatik yang baik. ${ }^{24}$ Para pemimpin dunia menolak keras tindakan yang dilakukan Korea Utara atas ketidakpatuhannya dengan resolusi Dewan Keamanan karena telah mengancam stabilitas keamanan. Selain itu dikhawatirkan juga dengan dilakukannya uji coba nuklir itu dapat menimbulkan radiasi yang nantinya dapat meluas dan menyebar di kawasan sekitarnya serta memberikan efek yang berbahaya bagi kelangsungan hidup masyarakatnya. ${ }^{25}$

\section{Sanksi atas Ketidakpatuhan Korea Utara terhadap Resolusi Dewan Keamanan PBB}

Penjatuhan sanksi oleh Dewan Keamanan PBB didasarkan pada tiga hal yang tertuang dalam Pasal 39 Piagam. Pertama, jika negara itu mengadakan tindakan-tindakan yang mengancam perdamaian dunia. Kedua, jika melanggar perdamaian. Ketiga, jika negara itu melancarkan suatu agresi terhadap negara lain.

Peranan Dewan Keamanan sehubungan dengan Pasal 39 Piagam PBB memberikan kewenangan pada organ tersebut

24 The Associated Press, 2016, Indo-Pasific Defense Forum, Uganda menghentikan kerja sama militer dengan Korea Utara, https://ipdefenseforum.com/id/uganda-menghentikan-kerja-samamiliter-dengan-korea-utara/, diakses pada 8 Juni Pukul 17.00 WITA.

25 Dian Wirengjurit, 2002, Kawasan Damai dan Bebas Senjata Nuklir, Pengertian Sejarah, dan Perkembangannya, Bandung: PT. Alumni, hlm. 359.

Uti Possidetis: Journal of International Law, Vol. 2, No. 1 (2021) 
untuk menentukan apakah suatu tindakan dikategorikan membahayakan atau tidak membahayakan bagi perdamaian dan keamanan internasional sehingga Dewan Keamanan diberikan hak untuk menentukan ada atau tidaknya ancaman terhadap perdamaian dan keamanan dunia sebelum Dewan Keamanan memberikan tindakan sesuai dengan Pasal 41 dan 42.

Akan tetapi, sanksi ekonomi bukanlah satu-satunya cara untuk menghentikan program pengembangan nuklir Korea Utara. Beberapa saat setelah Dewan Keamanan mengeluarkan resolusi, Korea Utara melakukan peluncuran nuklir kembali sebagai bentuk reaksi menentang tindakan Dewan Keamanan.

\section{Penangguhan Hak-hak Keanggotaan PBB}

Penangguhan terhadap hak-hak keanggotaan PBB pada umumnya merupakan suatu cara untuk mendorong agar suatu negara berhenti melakukan pelanggaran yang dilakukan secara terus menerus terhadap keputusan Dewan Keamanan dan prinsip-prinsip PBB sebagaimana yang diatur dalam Pasal 5 Piagam PBB. Penangguhan juga dilakukan sebagai langkah untuk menghindarkan anggota merintangi tindakan-tindakan pencegahan dan pemaksaan yang dikenakan oleh Dewan Keamanan.

Penangguhan yang diberikan meliputi hak untuk membuat perjanjian internasional bersama Dewan Keamanan PBB dalam membantu tugas Dewan Keamanan dalam memelihara perdamaian dan keamanan internasional 
sebagaimana yang tertuang dalam Pasal 43 ayat 3 Piagam PBB, hak untuk memberikan suara dalam suatu konferensi umum untuk melakukan peninjauan terhadap isi Piagam PBB sebagaimana yang tertuang dalam Pasal 109 ayat 1 Piagam PBB, hak memberikan suara dalam sidang Majelis Umum terkait pengambilan keputusan terhadap persoalan-persoalan yang tertuang dalam Pasal 18 ayat 2 Piagam PBB.

Dilakukannya penangguhan hak keanggotaan terhadap Korea Utara mengakibatkan Korea Utara tidak dapat berkontribusi dalam kerjasama pembuatan perjanjian internasional bersama Dewan Keamanan terkait dengan pemeliharan perdamaian dan keamanan internasional karena posisinya Korea Utara sebagai negara yang melakukan tindakan yang mengancam stabilitas keamanan negara melalui uji coba nuklirnya. Selain itu Korea Utara tidak memiliki hak suara dalam sebuah forum PBB dimana Korea Utara yang menjadi topik pembahasan dalam forum tersebut yang melakukan pelanggaran terhadap ketentuan Piagam PBB sebagaimana yang tertuang dalam Pasal 32 Piagam PBB.

\section{Pengusiran Suatu Negara dari Keanggotaan PBB}

Anggota PBB yang senantiasa melakukan pelanggaran terhadap prinsip-prinsip Piagam PBB dapat diusir dari keanggotaan PBB oleh Majelis Umum PBB atas rekomendasi Dewan Keamanan sebagaimana yang tertuang dalam Pasal 6 Piagam PBB. Pengusiran bukan suatu tindakan yang otomatis 
tetapi suatu tindakan yang diputuskan oleh dua badan utama PBB.

\section{Pengenaan Sanksi Militer}

Jika sanksi militer merupakan upaya terakhir yang dapat dilakukan, maka Dewan Keamanan berdasarkan Pasal 42 Piagam PBB dapat mengambil tindakan dengan mempergunakan angkatan udara, laut atau darat yang mungkin diperlukan untuk memelihara atau memulihkan perdamaian dan kemanan internasional termasuk juga demonstrasidemonstrasi, blokade dan tindakan-tindakan lain dengan mempergunakan angkatan udara, laut atau darat dari negara anggota PBB.

Pelaksanaan sanksi militer oleh Dewan Keamanan sebagaimana yang tertuang dalam Pasal 44 Piagam PBB dilakukan dengan meminta semua negara anggota PBB untuk turut serta memberikan kesanggupan untuk menyediakan angkatan bersenjata bagi Dewan Keamanan dan bantuanbantuan serta fasilitas-fasilitas termasuk pula hak-hak lalulintas yang dianggap perlu untuk memelihara perdamaian dan keamanan internasional sesuai dengan persetujuan atau persetujuan-persetujuan khusus.

Dewan Keamanan PBB memberikan sanksi atas program pengembangan nuklir Korea Utara, karena tindakan tersebut merupakan ancaman nyata bagi perdamaian dan keamanan dunia, tidak hanya bagi kawasan Semenanjung Korea, tetapi juga bagi seluruh dunia sehingga penerapan sanksi diarahkan 
untuk menjaga atau mengembalikan perdamaian dan keamanan internasional.

Terkait dengan beberapa sanksi yang dapat diberikan oleh Dewan Keamanan selain sanksi ekonomi, sanksi penangguhan hak-hak keanggotaan merupakan sanksi yang paling tepat diberikan kepada Korea Utara. Hal ini dikarenakan sanksi pengusiran keanggotaan merupakan cara terakhir yang dapat diambil jika suatu negara anggota terus menerus mengabaikan kewajibannya, sedangkan sanksi militer dapat menimbulkan risiko terjadinya perang dan jika perang terjadi maka situasi tersebut dapat menciptakan instabilitas keamanan yang tidak hanya dirasakan oleh negara-negara di kawasan Semenanjung Korea tetapi juga disekitar kawasan Asia Timur.

\section{Penutup}

Ketidakpatuhan Korea Utara terhadap sanksi ekonomi yang diberikan oleh Dewan Keamanan berdasarkan pasal 41 Piagam PBB, membuat Dewan Keamanan berupaya memberikan sanksi lain melalui Majelis Umum PBB atas rekomendasinya yakni sanksi penangguhan hak-hak keanggotaan sebagai sanksi yang paling tepat diberikan dibandingkan pengusiran negara dari keanggotaan dan sanksi militer yang dapat menimbulkan risiko terjadinya perang dan dapat menciptakan instabilitas keamanan bagi kawasan Semenanjung Korea hingga kawasan Asia Timur.

Selain memberikan sanksi, perundingan-perundingan dengan Korea Utara terkait denuklirisasi tetap harus 
dijalankan, terutama yang diinisiasi oleh Amerika Serikat dan Korea Selatan. Hal ini tidak lain bertujuan untuk menciptakan perdamaian di Semenanjung Korea dan juga dunia.

\section{Referensi}

\section{Instrumen Hukum}

Charter of The United Nations

\section{Buku}

Suwardi, S.S. 2004. Pengantar Hukum Organisasi Internasional. Jakarta: Universitas Indonesia Press.

Wirengjurit, Dian. 2002. Kawasan Damai dan Bebas Senjata Nuklir. Pengertian Sejarah. dan Perkembangannya. Bandung: PT. Alumni.

\section{Jurnal}

Arpan, M.F. Motivasi Korea Utara Memutuskan Hubungan Kerjasama Dengan Korea Selatan Di Kawasan Industri Kaesong. Jurnal Online Mahasiswa Fakultas Ilmu Sosial dan Ilmu Politik Universitas Riau. 5, (1), hlm. 1-15.

Sanjaya, I.W.N.A. Implementasi Resolusi Dewan Keamanan

Perserikatan Bangsa-Bangsa Nomor 2270 Tahun 2016 Tentang Uji Coba Senjata Nuklir Oleh Korea Utara. Jurnal Ilmu Hukum. 6, (1), hlm. 1-15.

\section{Internet}

BBC News. 2006. UN slaps sanctions on North Korea, http://news.bbc.co.uk/2/hi /asiapacific/6051704.stm. diakses pada 1 April 2020. Pukul 10.00 WITA.

BBC News. 2007. Perlucutan nuklir Korut rumit. http://www.bbc.co.uk/indonesia n/news/story/2007/03/070312_northkorea.shtml. diakses pada 1 April 2020. Pukul 13.00 WITA.

BBC NEWS. 2016. Kim Jong-un klaim Korut punya hulu ledak nuklir mini. https://www. bbc.com/indonesia/dunia/2016/03/160308_dunia_k 
orut_hulu_ledak_nuklir. diakses pada 7 April 2020. Pukul 08.00 WITA.

BBC News. 2017. North Korea's Berlin hostel targeted by German sanctions. https:// www.bbc.com/news/world-europe-39882199. diakses pada 8 Juni 2020. Pukul 15.00 WITA.

Chase Winter. 2017. DW Made For Minds. Germany To Strengthen Sanctions Against North Korea. https://www.dw.com/en/germany-to-strengthensanctions-against -north-korea/a-38777704. diakses pada 1 Juni 2020. Pukul 03.00 WITA.

Choirul Aminuddin. 2017. Myanmar Usir Diplomat Korea Utara Terkait Sanksi

PBB.

https://dunia.tempo.co/read/1026554/myanmarusir-diplomat-korea-utara-terk ait-sanksipbb/full\&view=ok. diakses pada 29 April 2020. Pukul 19.50 WITA.

Emirald Julio. 2017.

Oke News. https://news.okezone.com/read/2017/09/13/18/ 1774655/tegas-mesir-hentikan-kerjasama-militerdengan-korea-utara. diakses pada 08 Juni 2020. Pukul 14.00 WITA.

Euan McKirdy. North Korea announces it conducted nuclear test. http://editi on.cnn. com/2016/01/05/asia/north-korea-seismic-event/. diakses pada 4 April 2020. Pukul 08.00 WITA.

Gina Heeb. 2018. Sanctions are crippling North Korea's economy. $\quad$ https://markets.bus inessinsider.com/news/stocks/north-koreaeconomy-hit-by-sanctions-2018-7-10 27386898. diakses pada 28 April 2020. Pukul 23.00 WITA.

Happy Ferdian Syah Utomo. 2018. Terungkap Manisnya Bisnis Gelap Korea Utara di Mozambik. https://www.liputan6.com/global/read/3256360/te rungkap-manisny a-bisnis-gelap-korea-utara-dimozambik, diakses pada 1 April 2020. Pukul 19.00 WITA.

KBS WORLD RADIO. 2017. VOA: Portugis Memutus Hubungan Diplomatik dengan Korut. 
http://world.kbs.co.kr/service/news view.htm?lang =i\&Seq Code $=475$ 65. diakses pada 28 April 2020. Pukul 19.00 WITA.

Khairisa Ferida. 2017. Dubes Korea Utara Diminta Angkat Kaki dari Italia. https://www.liputan6.com/global/read/3114082/d ubes-korea-utara-diminta-an gkat-ka ki-dari-italia. diakses pada 29 April 2020. Pukul 20.15 WITA.

Khairisa Ferida. 2017. Kuwait Usir Dubes Korea Utara. https://www.liputan6.com/glo $\mathrm{bal} / \mathrm{read} / 3099122 /$ kuwait-usir-dubes-korea-utara. diakses pada 29 April 2020. Pukul 21.00 WITA.

Teguh Firmansyah. 2017. Pemerintah Spanyol Usir Dubes Korut. https://www.republ ika.co.id/berita/internasional/global/17/09/19/owi gqn377-pemerintah-spanyol- usir-dubes-korut. diakses pada 29 April 2020. Pukul 21.45 WITA.

The Associated Press. 2016. Indo-Pasific Defense Forum, Uganda menghentikan kerja sama militer dengan Korea Utara. https://ipdefenseforum.com/id/ugandameng hentikan-kerja-sama-militer-dengan-koreautara/. diakses pada 8 Juni 2020. Pukul 17.00 WITA.

The National Committee on North Korea. 2009. DPRK's foreign ministry vehemently refutes UNSC's 'Presidential Statement. http://www.ncnk.org/resources/public actions/KCNA_DPRK_Response_UNSC_April_13_09_St atement.doc. diakses pada 19 April 2020. Pukul 20.00 WITA.

United States Forces Korea. 2016. CFC begins Ulchi Freedom Guardian 2016 ROK-US Combined Forces Command, 2016 Eulji Freedom Guardian Practice. https://www .usfk.mil/Media/Press-Releases/Article/920965/cfcbegins-ulchi-freedom-guardi an-2016-2016/. diakses pada 6 April 2020. Pukul 21.00 WITA.

Yantina Debora. 2017. Cara Korea Utara Mengakali Embargo PBB, https://tirto. id/cara-korea-utara-mengakaliembargo-pbb-ckQh. diakses pada 1 April 2020. Pukul 14.00 WITA. 